\title{
Studi Kinerja Slow Sand Filter dengan Bantuan Lampu Light Emitting-Diode (LED) Putih
}

\author{
Carissa Y. Ekadewi dan Wahyono Hadi \\ Departemen Teknik Lingkungan, Fakultas Teknik Sipil, Lingkungan, dan Kebumian, \\ Institut Teknologi Sepuluh Nopember (ITS) \\ e-mail:wahyono@enviro.its.ac.id
}

\begin{abstract}
Abstrak - Pada penelitian ini dilakukan proses filtrasi dengan menggunakan slow sand filter sebagai salah satu metode dalam pengolahan air bersih. Selanjutnya dilakukan analisis efisiensi penurunan tingkat kekeruhan, total coliform, dan zat organik $\left(\mathrm{KMnO}_{4}\right)$ yang dapat diturunkan oleh unit slow sand filter untuk mengolah air sumur dengan bantuan lampu Light Emitting Diode (LED) putih dan adanya geotekstil dalam setiap unit slow sand filter. Variasi pada penelitian ini yaitu: jarak lampu ke air permukaan sebesar $20 \mathrm{~cm}$ dan $40 \mathrm{~cm}$ dengan rate filtrasi 0,3 m3/m2.jam dan 0,1 m3/m2.jam. Pada penelitian ini digunakan air baku yaitu air sumur di daerah Mulyorejo dengan nilai awal kekeruhan 8,43 NTU, nilai awal total coliform 16.000 per $100 \mathrm{ml}$ sampel, dan nilai awal zat organik $\left(\mathrm{KMnO}_{4}\right) 29,072 \mathrm{mg} / \mathrm{L}$. Dihasilkan bahwa efisiensi penurunan tingkat kekeruhan, total coliform, dan zat organik $\left(\mathrm{KMnO}_{4}\right)$ pada variasi jarak lampu sebesar $40 \mathrm{~cm}$ ke air permukaan dan rate filtrasi $0,1 \mathrm{~m} 3 / \mathrm{m} 2 / \mathrm{jam}$ adalah yang paling baik dengan nilai rata-rata efisiensi kekeruhan sebesar $96,71 \%$, total coliform sebesar 99,76\%, dan zat organik $\left(\mathrm{KMnO}_{4}\right)$ sebesar $89,96 \%$.
\end{abstract}

Kata Kunci- Kekeruhan, Lampu LED Putih, Slow Sand Filter, Total Coliform, Zat Organik

\section{PENDAHULUAN}

$\mathrm{A}^{\mathrm{I}}$ IR sumur merupakan sumber utama sebagai air baku air minum bagi masyarakat yang tinggal di daerah perkotaan. Air sumur adalah air tanah dangkal sampai kedalaman kurang dari 30 meter yang pada umumnya ada di kedalaman 15 meter dan dinamakan juga sebagai air tanah bebas karena lapis an air tanah tersebut tidak berada di dalam tekanan. Untuk memenuhi kebutuhan air sumur yang bersih terdapat tiga parameter, yaitu parameter fisik yang meliputi bau, rasa, warna dan kekeruhan. Parameter kedua adalah parameter kimia yang meliputi kimia organik dan kimia anorganik yang mengandung logam seperti $\mathrm{Fe}, \mathrm{Cu}, \mathrm{Ca}$ dan lain-lain. Parameter ketiga adalah parameter bakteriologi yang terdiri dari koliform fekal dan koliform total [1].

Dalam proses pengolahan air baku menjadi air minum diperlukan sistem pengolahan yang memenuhi standar kualitas yang ada agar hasilnya berkualitas tinggi dan tidak membahayakan kesehatan manusia. Sistem pengolahan yang dapat digunakan salah satunya adalah unit slow sand filter
(SSF). SSF merupakan teknologi pengolahan air yang memanfaatkan biofilm yang terbentuk pada media pasir untuk menghilangkan zat pencemar yang ada air baku. Bangunan ini dapat menyaring bakteri ataupun mikroorganisme yang terdapat pada air [2]. Di dalam SSF terdapat lapisan schmutzdecke yang terdiri dari alga yang berbentuk untaian benang dan berbagai jenis organisme lainnya termasuk plankton, diatoms, protozoa, rotifer, dan bakteri. Lapisan yang berupa lumpur tipis yang menutupi pasir tersebut mampu mendegradasi partikel tersuspensi, bakteri, dan bahan organik. Terbentuknya lapisan ini membantu menyisihkan $98-99.5 \%$ dari jumlah bakteri yang terdapat dari air baku [3]. Pembentukan lapisan schmutzdecke yang matang memerlukan waktu 2-3 minggu tergantung pada makanan yang tersedia (bahan organik pada air baku), kandungan oksigen serta suhu air yang cukup [4].

Unit SSF selama ini selalu menggunakan bantuan sinar matahari dalam proses pembentukan schmutzdecke. Suhu dari panasnya sinar matahari memengaruhi pertumbuhan bakteri yang ada di schmutzdecke. Sedangkan pada penelitian ini yang digunakan adalah lampu Light Emitting Diode (LED) yang berwarna putih. Light Emitting Diode (LED) adalah suatu semikonduktor yang memancarkan cahaya monokromatik atau bisa diartikan sebagai diode yang memancarkan cahaya bila dialirkan arus listrik. Lampu LED terdiri dari bahan/material semikonduktor yang memancarkan gelombang cahaya yang dapat dilihat oleh mata manusia dan memancarkannya dalam jumlah besar. Bahan semikonduktor dibungkus dalam plastik sehingga mengonsentrasikan cahaya yang dihasilkan pada arah tertentu [5]. Selain mengeluarkan cahaya, sinar LED juga menghasilkan panas. Suhu panas dari lampu LED berwarna putih juga dapat diatur sesuai dengan panas suhu matahari tergantung dari ukuran intensitas lampunya. Walaupun intensitas dan terangnya lampu LED tinggi, lampu LED memiliki efisiensi energi yang lebih tinggi dibandingkan lampu lain, yaitu hingga $80 \%$ sampai $90 \%$ lebih hemat energi dibanding lampu lain [6].

SSF pada umumnya jarang digunakan karena unit ini membutuhkan lahan yang luas sedangkan di daerah perkotaan yang memiliki harga tanah yang tinggi membuat unit SSF jarang dijadikan pertimbangan untuk dibangun sebagai sarana pengolahan air minum. Padahal biaya untuk sarana operasi sudah murah dikarenakan tidak membutuhkan bahan kimia apapun dan perawatannya juga mudah dilakukan [7]. Itulah 
sebabnya apabila bangunan SSF dapat dibangun menjadi bertingkat yang artinya di dalam ruangan yang tertutup, dan menggunakan lampu sebagai pengganti sinar matahari, maka unit SSF akan dapat menampung lebih banyak kapasitas dan tidak perlu membeli lahan yang luas untuk membangun unit tersebut terutama di daerah perkotaan. Parameter yang digunakan dalam penelitian ini adalah kekeruhan, total coliform, dan zat organik $\left(\mathrm{KMnO}_{4}\right)$. Variabel yang digunakan dalam penelitian ini, yaitu variasi kecepatan filtrasi sebesar 0,1 $\mathrm{m}^{3} / \mathrm{m}^{2}$.jam dan $0,3 \mathrm{~m}^{3} / \mathrm{m}^{2}$.jam, variasi jarak lampu LED ke air sebesar $20 \mathrm{~cm}$ dan $40 \mathrm{~cm}$ sebagai pengganti sinar matahari, dan penggunaan media geotekstil pada SSF.

Variasi jarak lampu LED ini dilakukan untuk melihat efisiensi penurunan zat pencemar pada air baku dengan adanya kontribusi lampu LED dalam proses SSF apakah semakin jauh lebih baik atau semakin dekat lebih baik. Penggunaan media geotekstil dikarenakan geotekstil dapat memperbaiki kualitas effluent yang dihasilkan dengan menurunkan kandungan TSS, bakteri, dan dapat mengakumulasi biomassa [4]. Berdasarkan penggunaan variasi variabel tersebut akan menunjukkan hasil effluent pada unit SSF yang berbeda antara SSF yang menggunakan lampu LED putih sebagai pengganti sinar matahari, SSF tanpa lampu LED putih yang diletakkan di dalam ruangan, dan SSF dengan sinar matahari.

\section{METODE DAN PROSEDUR PENELITIAN}

Penelitian ini terdiri atas tahap yaitu tahap penelitian pendahuluan, pelaksanaan penelitian, analisa data penelitian dan pembahasan serta penarikan kesimpulan.

\section{A. Penelitian Pendahuluan}

Penelitian pendahuluan bertujuan untuk menentukan sumber air baku yang digunakan dalam pengolahan menggunakan slow sand filter. Air baku yang dipilih adalah air sumur. Air sumur ini tidak mengandung kadar garam yang tinggi karena unit slow sand filter ini memerlukan tumbuhnya mikroorganisme dalam lapisan biofilm untuk menurunkan zatzat pencemar dalam air minum seperti kekeruhan, kandungan bakteri coliform, dan kandungan zat organik. Sedangkan air dengan kadar garam tinggi tidak akan memiliki mikroorganisme yang dapat tumbuh.

Parameter yang diuji adalah kekeruhan, total coliform, dan zat organik $\left(\mathrm{KMnO}_{4}\right)$. Parameter kekeruhan dipilih sebagai salah satu parameter fisik yang dianalisis dan karena bila kekeruhan di atas $50 \mathrm{NTU}$, dapat berpengaruh terhadap kinerja slow sand filter yang menjadi lebih cepat mengalami clogging sehingga tidak bisa bekerja secara optimal [7]. Pada air sumur yang dijadikan air baku memiliki nilai kekeruhan 8,43 NTU. Parameter total coliform dipilih sebagai salah satu parameter biologi yang dianalisis dan pada air baku yang dipilih didapatkan nilai total coliform sebesar 16.000 MPN Index/100 $\mathrm{mL}$ sedangkan parameter zat organik dipilih sebagai salah satu parameter kimia yang dianalisis dan nilai zat organik pada air baku sebesar 29,072 mg/L. Selain parameter tersebut dilakukan juga pengukuran intensitas cahaya lampu LED puth masingmasing reaktor dengan menggunakan alat lux meter dan hasilnya, yaitu pada reaktor dengan jarak lampu $20 \mathrm{~cm}$ sebesar 590 lux dan pada reaktor dengan jarak lampu $40 \mathrm{~cm}$ sebesar 221 lux serta intensitas cahaya pada reaktor di dalam ruangan sebesar 107 lux dan pada reaktor di luar ruangan sebesar 8000 lux.

\section{B. Pelaksanaan Penelitian}

Penelitian dilakukan selama 24 jam terus menerus selama 5 hari untuk masing-masing variasi kecepatan filtrasi. Air sampel yang digunakan adalah air sumur di depan Kantor Urusan Agama Mulyorejo, Surabaya. Variabel yang digunakan pada penelitian ini adalah:

1. Kecepatan Filtrasi

2. Jarak Lampu ke Air Permukaan

Penelitian ini dilakukan dengan menggunakan 4 reaktor dan dijalankan bergantian setiap kecepatan filtrasi. Adapun 4 reaktor sebagai berikut:

1. Reaktor kontrol yang tidak menggunakan lampu LED putih terletak di luar ruangan.

2. Reaktor kontrol yang tidak menggunakan lampu LED putih terletak di dalam ruangan.

3. Reaktor dengan lampu LED putih berjarak $20 \mathrm{~cm}$ dari air permukaan

4. Reaktor dengan lampu LED putih berjarak $40 \mathrm{~cm}$ dari air permukaan

Sebelum dilakukan penelitian utama, ada proses aklimatisasi yang dilakukan terlebih dahulu selama 2 minggu dengan perkiraan media telah ditumbuhi biofilm. Lalu dilakukan penelitian utama dengan kecepatan filtrasi $0,3 \mathrm{~m}^{3} / \mathrm{m}^{2}$.jam selama 5 hari pertama pada seluruh reaktor dan 5 hari berikutnya dengan kecepatan $0,1 \mathrm{~m}^{3} / \mathrm{m}^{2}$.jam.

\section{Analisis Data}

Analisis data dan pembahasan dilakukan setelah mendapatkan hasil analisis laboratorium. Data yang akan dianalisis dalam penelitian ini adalah hasil analisis laboratorium mengenai kekeruhan, total coliform, dan zat organik $\left(\mathrm{KMnO}_{4}\right)$ pada inlet dan outlet sehingga dapat diketahui berapa efisiensi penurunan dari slow sand filter untuk masing-masing parameter. Parameter tingkat kekeruhan dianalisis dengan menggunakan turbiditymeter, parameter total coliform dianalisis dengan metode Most Probable Number (MPN) dengan Tabel Hopkins sebagai acuan dalam menentukan jumlah kandungan bakteri coliform dalam sampel air, dan zat organik dengan metode Permanganate Value (PV).

\section{HASIL DAN PEMBAHASAN}

\section{A. Aklimatisasi}

Aklimatisasi dilakukan sebelum pengoperasian dengan variasi kecepatan yang pertama dimulai untuk membentuk lapisan biofilm di media filter serta membuat media filter beradaptasi dengan air baku. Aklimatisasi dioperasikan dengan kecepatan $0,3 \mathrm{~m}^{3} / \mathrm{m}^{2}$.jam selama 2 minggu. Pada akhir minggu pertama dan akhir minggu kedua dilakukan analisis ketiga 
parameter dan didapatkan nilai efisiensi penurunan yang semakin meningkat pada akhir minggu pertama dan akhir minggu kedua. Selain itu juga dilakukan analisis bakteri yang ada di dalam setiap reaktor pada lapisan coklat yang muncul di atas geotekstil dengan metode TPC (Total Plate Count). Lapisan coklat inilah yang berupa lapisan biofilm atau lapisan schmutzdecke. Hasil dari penelitian bakteri ini adalah adanya bakteri pada setiap reaktor. Pada reaktor dengan lampu LED putih berjarak $40 \mathrm{~cm}$ ada 10900 koloni bakteri, lalu pada reaktor dengan lampu LED putih berjarak $20 \mathrm{~cm}$ ada 8000 koloni bakteri yang muncul. Sedangkan pada reaktor kontrol yang diletakkan di dalam ruangan ada 1260 koloni bakteri dan pada reaktor kontrol yang diletakkan di luar ruangan terdapat 660 koloni bakter yang muncul. Dengan adanya bakteri pada tiap reaktor disimpulkan bahwa lapisan schmutzdecke telah muncul dan telah siap dioperasikan.

\section{B. Pengoperasian dengan Variasi Kecepatan Filtrasi Pertama}

Pada proses aklimatisasi, kecepatan yang digunakan adalah $0,3 \mathrm{~m}^{3} / \mathrm{m}^{2}$.jam agar media filter dapat beradaptasi dengan baik dan dapat dilanjutkan ke pengoperasian variasi kecepatan filtrasi pertama dimana proses filtrasi dijalankan dengan kecepatan filtrasi sebesar $0,3 \mathrm{~m}^{3} / \mathrm{m}^{2}$.jam.

\section{Penurunan Tingkat Kekeruhan}

Pada proses pengoperasian unit SSF ini berjalan dengan kecepatan filtrasi $0,3 \mathrm{~m}^{3} / \mathrm{m}^{2}$.jam dan diamati efisiensi penurunan tingkat kekeruhan dari hasil effluent tiap reaktor dan pada inlet sebagai perbandingan untuk mendapatkan efisiensi removal. Pada Gambar. 1. di bawah ini dapat dilihat di hari kedua dan keempat efisiensi removal nilai kekeruhan pada seluruh reaktor menurun dikarenakan schmutzdecke yang telah tumbuh di media filter belum dapat bekerja dengan stabil walaupun setelah dilakukan aklimatisasi selama 14 hari. Hal ini juga terjadi dikarenakan nilai pada inlet di hari kedua dan keempat yang lebih kecil dibandingkan nilai inlet pada hari lainnya. Sehingga efisiensi pada hari kedua dan keempat jauh lebih rendah dibandingkan hari lainnya walaupun nilai kekeruhan antara hari pertama dan kedua serta hari ketiga dan keempat tidak berbeda terlalu jauh.

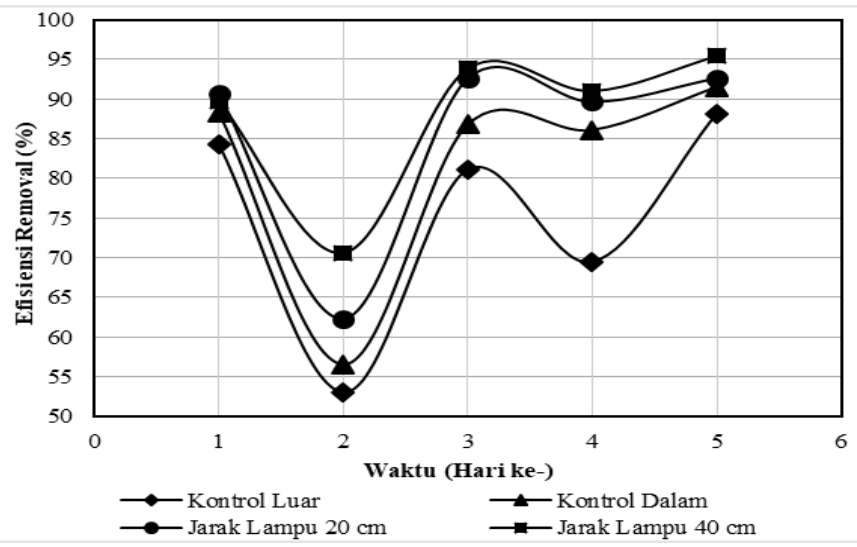

Gambar. 1. Efisiensi penurunan tingkat kekeruhan dengan kecepatan filtrasi $0,3 \mathrm{~m}^{3} / \mathrm{m}^{2}$. jam

Nilai tertinggi tingkat kekeruhan di inlet adalah pada pengambilan sampel hari ke-5 dengan nilai 7,2 NTU dan nilai terendah terjadi di hari ke-5, yaitu 0,33 NTU. Nilai kekeruhan pada outlet di seluruh reaktor telah ada di bawah nilai kekeruhan yang diperbolehkan dalam standar baku mutu yang ada di PERMENKES no.492/Menkes/Per/IV/2010 yang adalah 5 NTU. Pada Gambar. 1. juga terlihat garis yang ada di paling atas adalah yang reaktor dengan lampu LED putih berjarak 40 $\mathrm{cm}$ dari air permukaan dengan nilai rata-rata efisiensi penurunan kekeruhan $88,12 \%$, lalu pada urutan kedua adalah reaktor dengan lampu LED puth berjarak $20 \mathrm{~cm}$ dari air permukaan dengan nilai rata-rata efisiensi penurunan kekeruhan sebesar $85,56 \%$, selanjutnya adalah reaktor kontrol yang diletakkan di dalam ruangan dengan nilai rata-rata efisiensi penurunan kekeruhan sebesar $81,85 \%$ dan yang terakhir adalah reaktor kontrol yang diletakkan di luar ruangan dengan nilai rata-rata efisiensi penurunan kekeruhan sebesar $75,23 \%$.

\section{Penyisihan Total Coliform}

Setelah menganalisis efisiensi penurunan kekeruhan, selanjutnya diamati efisiensi penyisihan total coliform dari hasil effluent tiap reaktor dan inlet sebagai perbandingan untuk menentukan efiensi removal. Selanjutnya sampel akan dianalisis total coliformnya dengan metode MPN (Most Probable Number). Pada Gambar. 2. di bawah dapat dilihat bahwa grafik efisiensi removal total coliform pada hari pertama hingga hari ke-5 pada seluruh reaktor mengalami peningkatan pada efisiensi penurunan total coliform. Peningkatan pada hari ke-1 hingga ke-4 pada seluruh reaktor kecuali reaktor dengan jarak lampu ke air permukaan sebesar $40 \mathrm{~cm}$ tersebut menunjukkan schmutzdecke telah tumbuh dengan maksimal namun belum stabil dikarenakan masih mengalami peningkatan yang terlalu tinggi. Pada hari ke-4 hingga ke-5 menunjukkan peningkatan yang lebih stabil pada seluruh reaktor. Itu artinya schmutzdecke yang terbentuk sudah mulai bekerja dengan stabil dalam menurunkan total coliform.

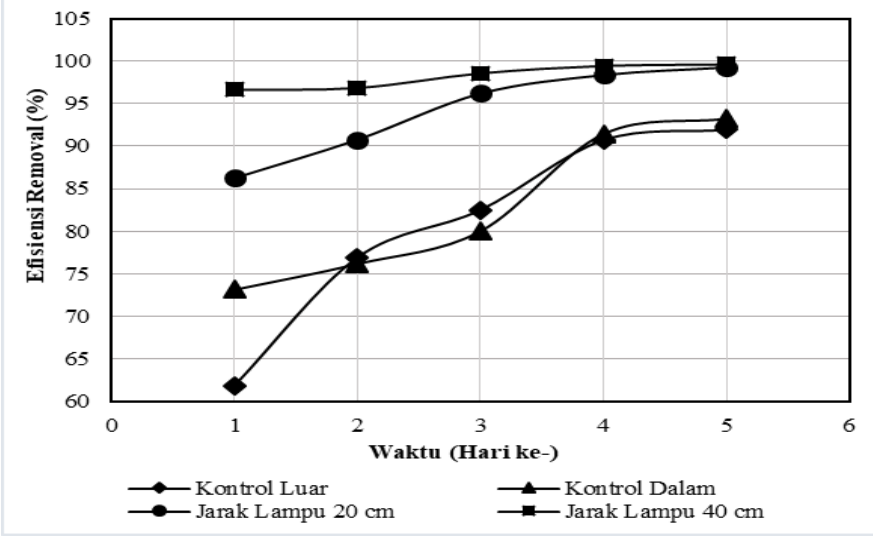

Gambar. 2. Efisiensi removal total coliform dengan kecepatan filtrasi 0,3 $\mathrm{m}^{3} / \mathrm{m}^{2} . \mathrm{jam}$

Nilai tertinggi total coliform di inlet adalah pada pengambilan sampel hari ke-5 dengan nilai 3100 MPN 
Index/100 $\mathrm{mL}$ dan nilai terendah terjadi di hari ke-2, yaitu 1300 MPN Index/ $100 \mathrm{~mL}$. Nilai total coliform yang telah disisihkan hingga paling rendah ada di hasil outlet reaktor dengan lampu LED putih dengan jarak $40 \mathrm{~cm}$ ke air permukaan pada hari ke-5 yang berupa 12 MPN Index $/ 100 \mathrm{~mL}$. Nilai tersebut masih di atas nilai maksimum yang diperbolehkan dalam standar baku mutu yang ada di PERMENKES No. 492/Menkes/Per/IV/2010 yang adalah 0/100 mL. Pada Gambar. 2. juga terlihat garis yang ada di paling atas adalah yang reaktor dengan lampu LED putih berjarak $40 \mathrm{~cm}$ dari air permukaan dengan nilai rata-rata efisiensi penurunan kekeruhan $98,22 \%$, lalu pada urutan kedua adalah reaktor dengan lampu LED putih berjarak $20 \mathrm{~cm}$ dari air permukaan dengan nilai rata-rata efisiensi penurunan kekeruhan sebesar $94,16 \%$, selanjutnya adalah reaktor kontrol yang diletakkan di dalam ruangan dengan nilai rata-rata efisiensi penurunan kekeruhan sebesar 82,79\% dan yang terakhir adalah reaktor kontrol yang diletakkan di luar ruangan dengan nilai rata-rata efisiensi penurunan kekeruhan sebesar $80,79 \%$.

\section{Penyisihan Zat Organik $\left(\mathrm{KMnO}_{4}\right)$}

Setelah sampel dianalisis efisiensi penurunan kekeruhan dan total coliform, selanjutnya sampel akan dianalisis zat organiknya $\left(\mathrm{KMnO}_{4}\right)$ dengan metode Permanganate Value (PV). Berdasarkan Gambar. 3. hasil grafik efisiensi removal zat organik $\left(\mathrm{KMnO}_{4}\right)$ sangat fluktuatif. Dapat dilihat pada hari ke-2 dan ke-5 mengalami penurunan nilai efisiensi removal. Hal ini dikarenakan lapisan schmutzdecke masih beradaptasi setelah masa aklimatisasi sehingga hasilnya masih belum stabil. Selain itu juga disebabkan nilai inlet yang semakin kecil pada hari ke2, ke-3, dan ke-5 dibandingkan hari pertama dan hari ke-4 sehingga efisiensi zat organik $\left(\mathrm{KMnO}_{4}\right)$ yang dapat diturunkan juga semakin kecil. Pada hari ke-2 hingga hari ke-4 grafik efisiensi penurunan zat organik semakin naik pada seluruh reaktor dikarenakan nilai inlet dari yang kecil hingga semakin besar.

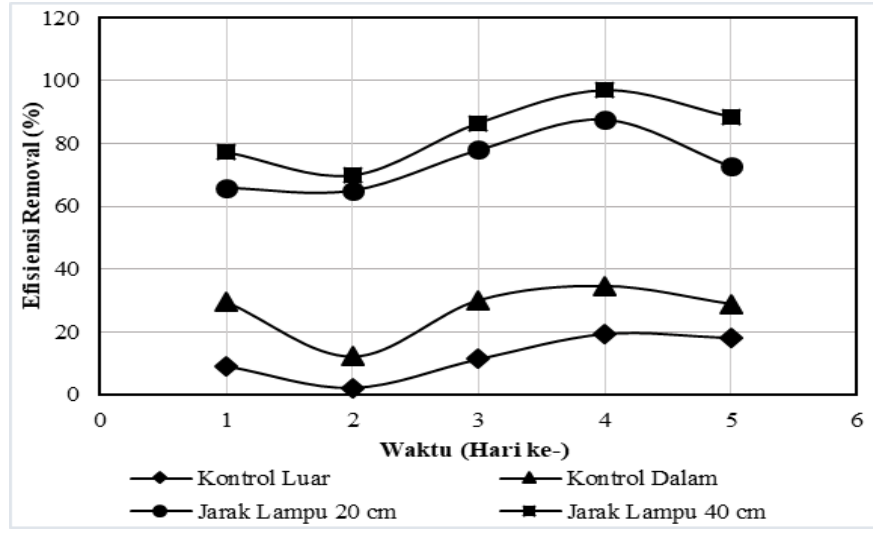

Gambar. 3. Efisiensi removal zat organik $\left(\mathrm{KMnO}_{4}\right)$ dengan kecepatan filtrasi $0,3 \mathrm{~m}^{3} / \mathrm{m}^{2}$.jam

Nilai tertinggi zat organik $\left(\mathrm{KMnO}_{4}\right)$ di inlet adalah pada pengambilan sampel hari ke-1 dengan nilai $27,81 \mathrm{mg} / \mathrm{L}$ dan nilai terendah terjadi di hari ke-5, yaitu $23,13 \mathrm{mg} / \mathrm{L}$. Nilai zat organik $\left(\mathrm{KMnO}_{4}\right)$ yang telah disisihkan hingga paling rendah ada di hasil outlet reaktor dengan lampu LED putih dengan jarak 40 $\mathrm{cm}$ ke air permukaan pada hari ke-4 yang berupa $0,76 \mathrm{mg} / \mathrm{L}$.
Nilai tersebut sudah di bawah nilai maksimum yang diperbolehkan dalam standar baku mutu yang ada di PERMENKES No. 492/Menkes/Per/IV/2010 yang adalah 10 $\mathrm{mg} / \mathrm{L}$. Pada Gambar. 3. juga terlihat garis yang ada di paling atas adalah yang reaktor dengan lampu LED putih berjarak 40 $\mathrm{cm}$ dari air permukaan dengan nilai rata-rata efisiensi penurunan kekeruhan $83,86 \%$, lalu pada urutan kedua adalah reaktor dengan lampu LED putih berjarak $20 \mathrm{~cm}$ dari air permukaan dengan nilai rata-rata efisiensi penurunan kekeruhan sebesar $73,84 \%$, selanjutnya adalah reaktor kontrol yang diletakkan di dalam ruangan dengan nilai rata-rata efisiensi penurunan kekeruhan sebesar $27,08 \%$ dan yang terakhir adalah reaktor kontrol yang diletakkan di luar ruangan dengan nilai rata-rata efisiensi penurunan kekeruhan sebesar $11,97 \%$.

\section{Pengoperasian dengan Variasi Kecepatan Filtrasi Kedua}

Pada pengoperasian ini dilakukan proses filtrasi dengan variasi kecepatan filtrasi ketiga, yaitu $0,1 \mathrm{~m}^{3} / \mathrm{m}^{2}$.jam. Variasi kecepatan filtrasi yang dilakukan dimulai dari yang paling cepat ke yang lebih lambat agar lapisan lumpur schmutzdecke yang mulai terbentuk tidak tergerus dan turut larut keluar sampai outlet. Bila penelitian dimulai dari kecepatan filtrasi yang paling cepat, maka lapisan schmutzdecke yang telah terbentuk tidak akan tergerus karena kecepatan filtrasi selanjutnya lebih lambat yang artinya air yang masuk ke reaktor juga lebih lambat dibandingkan sebelumnya.

\section{Penurunan Tingkat Kekeruhan}

Pada proses pengoperasian unit SSF ini berjalan dengan kecepatan filtrasi $0,1 \mathrm{~m}^{3} / \mathrm{m}^{2}$.jam dan diamati efisiensi penurunan tingkat kekeruhan dari hasil effluent tiap reaktor dan pada inlet sebagai perbandingan untuk mendapatkan efisiensi removal. Pada Gambar. 4. di bawah ini dapat dilihat hari ke-1 hingga ke-3 nilai efisiensi removal telah stabil yang artinya schmutzdecke telah terbentuk dengan sempurna dan dapat bekerja dengan stabil. Proses mechanical straining dan sedimentasi yang terjadi pada unit slow sand filter juga telah dapat bekerja dengan baik. Pada hari ke-4 nilai efisiensi removal tingkat kekeruhan semakin naik yang menunjukkan keempat reaktor telah mencapai kondisi paling optimal. Pada hari ke-5 efisiensi removal tingkat kekeruhan menurun dikarenakan ada kemungkinan terjadinya clogging. Clogging terjadi dikarenakan filter yang digunakan tidak pernah dicuci atau dikuras sejak dioperasikan untuk aklimatisasi sehingga bakteri, zat organik, dan lain sebagainya semakin menumpuk di media filter dan mengakibatkan clogging. 


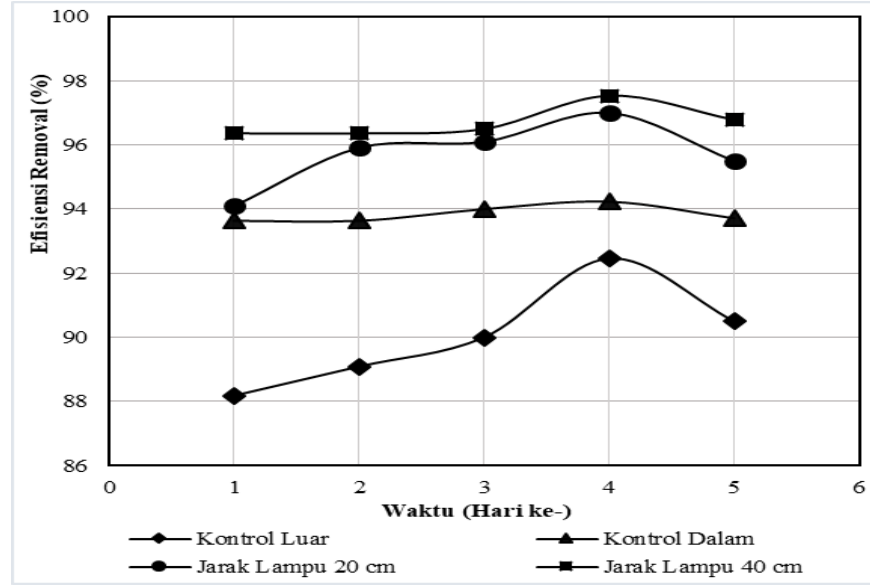

Gambar. 4. Efisiensi penurunan tingkat kekeruhan dengan kecepatan filtrasi $0,1 \mathrm{~m}^{3} / \mathrm{m}^{2}$.jam

Nilai tertinggi tingkat kekeruhan di inlet adalah pada pengambilan sampel hari ke-5 dengan nilai 14 NTU dan nilai terendah terjadi di hari ke-3, yaitu 10 NTU. Nilai inlet yang tertinggi masih di atas standar baku mutu yang ada di PERMENKES no. 492/Menkes/Per/IV/2010. Namun setelah diolah di filter SSF, tidak ada yang di atas 5 NTU. Pada Gambar. 4. juga terlihat garis yang ada di paling atas adalah yang reaktor dengan lampu LED putih berjarak $40 \mathrm{~cm}$ dari air permukaan dengan nilai rata-rata efisiensi penurunan kekeruhan $96,71 \%$, lalu pada urutan kedua adalah reaktor dengan lampu LED putih berjarak $20 \mathrm{~cm}$ dari air permukaan dengan nilai rata-rata efisiensi penurunan kekeruhan sebesar $95,72 \%$, selanjutnya adalah reaktor kontrol yang diletakkan di dalam ruangan dengan nilai rata-rata efisiensi penurunan kekeruhan sebesar $93,84 \%$ dan yang terakhir adalah reaktor kontrol yang diletakkan di luar ruangan dengan nilai rata-rata efisiensi penurunan kekeruhan sebesar 90,05\% .

\section{Penyisihan Total Coliform}

Setelah menganalisis efisiensi penurunan kekeruhan, selanjutnya diamati efisiensi penyisihan total coliform dari hasil effluent tiap reaktor dan inlet sebagai perbandingan untuk menentukan efiensi removal. Pada Gambar. 5. di bawah dapat dilihat bahwa grafik efisiensi removal total coliform pada seluruh reaktor masih stabil namun semakin menurun. Hal ini dikarenakan media filter pada reaktor yang tidak dicuci atau dikuras dari awal aklimatisasi sehingga terjadinya penumpukan partikel dalam media filter yang berlebih dan memengaruhi kinerja filter. Selain itu juga dikarenakan kondisi mikroorganisme dalam filter yang sudah mulai kenyang sehingga saat total coliform pada air baku tinggi, mikroorganisme tersebut tidak mampu lagi untuk memakannya. Karena mikroorganisme tidak mampu untuk memakan bakterinya maka bakteri akan menumpuk dan menyebabkan terjadinya clogging. Grafik di bawah ini juga menunjukkan nilai efisiensi removal yang paling bagus dibandingkan variasi kecepatan filtrasi sebelumnya.

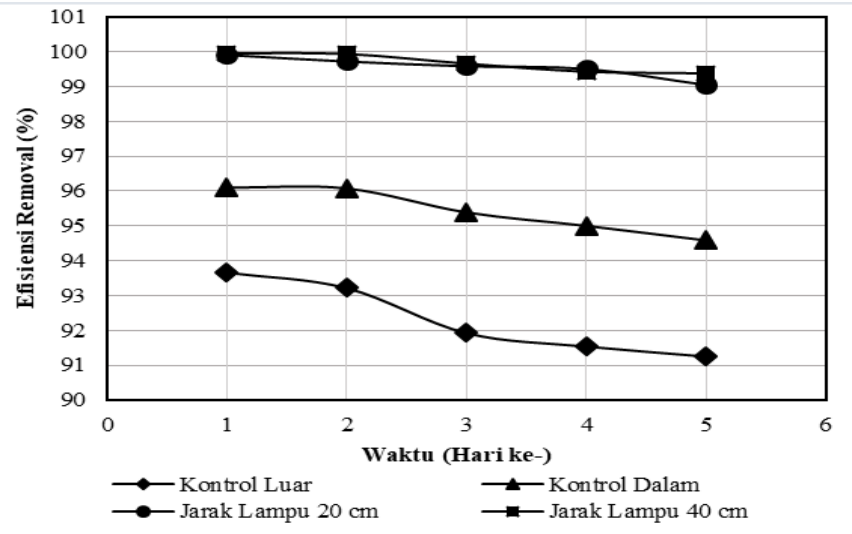

Gambar. 5. Efisiensi removal total coliform dengan kecepatan filtrasi 0,1 $\mathrm{m}^{3} / \mathrm{m}^{2}$.jam

Nilai tertinggi total coliform di inlet adalah pada pengambilan sampel hari ke-1 dengan nilai 4100 MPN Index $/ 100 \mathrm{~mL}$ dan nilai terendah terjadi di hari ke-5, yaitu 2400 MPN Index/ $100 \mathrm{~mL}$. Nilai total coliform yang telah disisihkan hingga paling rendah ada di hasil outlet reaktor dengan lampu LED putih dengan jarak $40 \mathrm{~cm}$ ke air permukaan yang berupa 2 MPN Index/100 mL. Namun nilai tersebut masih di atas nilai maksimum yang diperbolehkan dalam standar baku mutu yang ada di PERMENKES No. 492/Menkes/Per/IV/2010 yang adalah 0/100 mL. Pada Gambar. 5. juga terlihat garis yang ada di paling atas adalah yang reaktor dengan lampu LED putih berjarak 40 $\mathrm{cm}$ dari air permukaan dengan nilai rata-rata efisiensi penurunan kekeruhan 99,67\%, lalu pada urutan kedua adalah reaktor dengan lampu LED putih berjarak $20 \mathrm{~cm}$ dari air permukaan dengan nilai rata-rata efisiensi penurunan kekeruhan sebesar 99,55\%, selanjutnya adalah reaktor kontrol yang diletakkan di dalam ruangan dengan nilai rata-rata efisiensi penurunan kekeruhan sebesar $95,43 \%$ dan yang terakhir adalah reaktor kontrol yang diletakkan di luar ruangan dengan nilai rata-rata efisiensi penurunan kekeruhan sebesar $92,32 \%$.

\section{Penyisihan Zat Organik $\left(\mathrm{KMnO}_{4}\right)$}

Setelah sampel dianalisis efisiensi penurunan kekeruhan dan total coliform, selanjutnya sampel akan dianalisis zat organiknya $\left(\mathrm{KMnO}_{4}\right)$ dengan metode Permanganate Value (PV). Pada Gambar. 6. di bawah menunjukkan pada reaktor dengan lampu LED putih berjarak $20 \mathrm{~cm}$ dan $40 \mathrm{~cm}$ dari permukaan air di hari ke-4 dan ke-5 semakin menurun dikarenakan ada kemungkinan terjadinya clogging yang disebabkan tidak dilakukan pencucian media filter dari awal aklimatisasi. Hal ini juga terjadi pada kedua reaktor kontrol namun pada hari yang berbeda. Untuk kedua reaktor kontrol terjadi penurunan efisiensi removal pada hari ke-5. Namun hasil penurunan efisiensi removal zat organik $\left(\mathrm{KMnO}_{4}\right)$ pada variasi kecepatan filtrasi ini masih lebih bagus dibandingkan dengan hasil dari variasi kecepatan filtrasi sebelumnya. Efisiensi removal yang semakin menurun juga disebabkan mikroorganisme di dalam filter sedang dalam kondisi kenyang dan tidak mampu memakan zat organik lagi sehingga 
menyebabkan efisiensi penurunan zat organik dalam air baku lebih kecil [7].

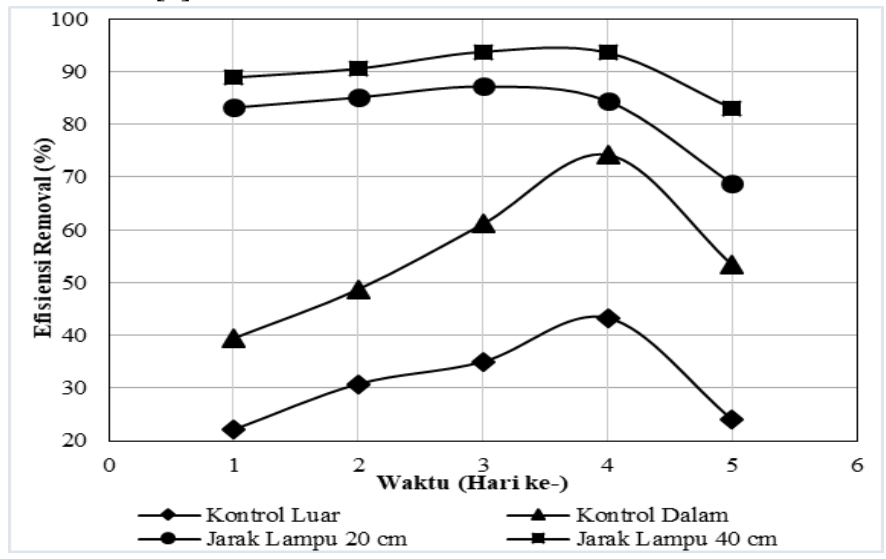

Gambar. 6. Efisiensi removal zat organik $\left(\mathrm{KMnO}_{4}\right)$ dengan kecepatan filtrasi $0,1 \mathrm{~m}^{3} / \mathrm{m}^{2}$.jam

Nilai zat organik $\left(\mathrm{KMnO}_{4}\right)$ yang telah disisihkan hingga paling rendah ada di hasil outlet reaktor dengan lampu LED putih dengan jarak $40 \mathrm{~cm}$ ke air permukaan pada hari ke-3 yang berupa $1,42 \mathrm{mg} / \mathrm{L}$. Nilai tersebut sudah di bawah nilai maksimum yang diperbolehkan dalam standar baku mutu yang ada di PERMENKES No. 492/Menkes/Per/IV/2010 yang adalah $10 \mathrm{mg} / \mathrm{L}$. Pada Gambar. 6. juga terlihat garis yang ada di paling atas adalah yang reaktor dengan lampu LED putih berjarak 40 $\mathrm{cm}$ dari air permukaan dengan nilai rata-rata efisiensi penurunan kekeruhan $89,96 \%$, lalu pada urutan kedua adalah reaktor dengan lampu LED putih berjarak $20 \mathrm{~cm}$ dari air permukaan dengan nilai rata-rata efisiensi penurunan kekeruhan sebesar $81,72 \%$, selanjutnya adalah reaktor kontrol yang diletakkan di dalam ruangan dengan nilai rata-rata efisiensi penurunan kekeruhan sebesar 55,36\% dan yang terakhir adalah reaktor kontrol yang diletakkan di luar ruangan dengan nilai rata-rata efisiensi penurunan kekeruhan sebesar $31,04 \%$.

\section{KESIMPULAN}

Adapun kesimpulan atau ringkasan yang didapatkan dari penelitian ini sebagai berikut:

1) Reaktor dengan kontribusi lampu LED putih dengan jarak $40 \mathrm{~cm}$ dari air permukaan adalah reaktor yang menurunkan parameter tingkat kekeruhan, total coliform, dan zat organik $\left(\mathrm{KMnO}_{4}\right)$ yang paling besar untuk semua variasi kecepatan filtrasi dibandingkan reaktor lainnya. Lalu urutan nomor dua adalah reaktor dengan kontribusi lampu LED putih dengan jarak $20 \mathrm{~cm}$ dari air permukaan diikuti dengan reaktor kontrol yang diletakkan di dalam ruangan, lalu urutan terakhir adalah reaktor kontrol yang diletakkan di luar ruangan. Adapun nilai rata-rata efisiensi removal dengan kontribusi lampu LED putih berjarak $40 \mathrm{~cm}$ dari air permukaan sebagai berikut:
- Parameter kekeruhan dengan kecepatan filtrasi 0,3 $\mathrm{m}^{3} / \mathrm{m}^{2}$.jam sebesar $88,12 \%$, dan dengan kecepatan filtrasi $0,1 \mathrm{~m}^{3} / \mathrm{m}^{2}$.jam sebesar $96,71 \%$.

- Parameter total coliform dengan kecepatan filtrasi 0,3 $\mathrm{m}^{3} / \mathrm{m}^{2}$.jam sebesar $98,22 \%$ dan dengan kecepatan filtrasi $0,1 \mathrm{~m}^{3} / \mathrm{m}^{2}$.jam sebes ar $99,67 \%$.

- Parameter zat organik $\left(\mathrm{KMnO}_{4}\right)$ dengan kecepatan filtrasi $0,3 \mathrm{~m}^{3} / \mathrm{m}^{2}$.jam sebesar $83,86 \%$ dan dengan kecepatan filtrasi $0,1 \mathrm{~m}^{3} / \mathrm{m}^{2}$.jam sebesar $89,96 \%$.

2) Kecepatan filtrasi $0,1 \mathrm{~m}^{3} / \mathrm{m}^{2}$.jam memiliki nilai paling tinggi dalam menurunkan parameter kekeruhan, total coliform, dan zat organik $\left(\mathrm{KMnO}_{4}\right)$ dibandingkan kecepatan filtrasi $0,3 \mathrm{~m}^{3} / \mathrm{m}^{2}$.jam. Lalu reaktor yang menggunakan lampu LED putih dengan jarak $40 \mathrm{~cm}$ ke air permukaan memiliki nilai paling tinggi dalam menurunkan parameter kekeruhan, total coliform, dan zat organik $\left(\mathrm{KMnO}_{4}\right)$ dibandingkan reaktor yang menggunakan lampu LED putih dengan jarak $20 \mathrm{~cm}$.

\section{DAFTAR PUSTAKA}

[1] Yusuf, Y., Nisma, F., dan Rusdi, N. K. 2011. Analisa Kandungan Air Sumur Warga RT 12, 17, dan 18 RW 09 Kelurahan Kelapa Dua Wetan Kecamatan Ciracas, Jakarta Timur. Prosiding Penelitian Bidang Ilmu Eksakta. Jakarta: UHAMKA.

[2] Amalia, A. 2014. Pembentukan Lapisan Schmutzdecke pada Unit Slow Sand Filter untuk Pengolahan Air Payau Ditinjau dari Parameter N Total, P Total, Total Coli, dan COD. Surabaya: Tugas Akhir untuk Memperoleh Gelar Sarjana Teknik Lingkungan, Institut Teknologi Sepuluh Nopember

[3] Dini. P. R., Fitriani, N., dan Hadi, W. 2013. Pengaruh Penambahan Geotekstil pada Unit Slow Sand Filter untuk Mengolah Air Siap Minum. Prosiding Seminar Nasional Manajemen Teknologi XVIII. Surabaya: Jurusan Teknik Lingkungan FT SP-ITS

[4] Ayuningtyas, Fitriani, N., dan Hadi, W. 2013. Pengaruh Ketebalan Media Geotextile dan Arah Aliran Slow Sand Filter Rangkaian Seri untuk Menyisihkan P Total dan $N$ Total. Jurnal Sains dan Seni POMITS, 2(1), hal. 26-29.

[5] Syafriyudin, Priyambodo, S., Saudah, S., dan Ledhe N. T. 2015. Pengaruh Variabel Warna Lampu LED terhadap Pertumbuhan Tanaman Krisan. Prosiding Seminar Nasional Teknik Industri. Yogyakarta: Institut Sains dan Teknologi AKPRIND

[6] Nayomi, H. dan Rahardjo, A. 2013. Peluang Pemanfaatan Lampu LED sebagai Sumber Penerangan. Depok: Tugas Akhir untuk Memperoleh Gelar Sarjana Fakultas Teknik Program St udi Teknik Elektro, Universitas Indonesia

[7] Adlin, I. 2012. Analisis Penggunaan Upflow Slow Sand Filter untuk Pengolahan Air Sumur menjadi Air Minum dengan Variasi Ketebalan Media dan Kecepatan Filtrasi. Surabaya: Tugas Akhir untuk Memperoleh Gelar Sarjana Teknik Lingkungan, Institut Teknologi Sepuluh Nopember

[8] Peraturan Menteri Kesehatan Republik Indonesia Nomor 492/MENKES/PER/IV/2010 tentang Persyaratan Kualitas Air Minum. 